\title{
Psychosocial job factors and chronic pain: analysis in two municipal schools in Serrana/SP
}

\author{
Fatores psicossociais do trabalho e dor crônica: análise em duas escolas da rede municipal de \\ educação em Serrana/SP
}

Keyla Neves da Silva1, Fabiana Caetano Martins Silva e Dutra²

DOI 10.5935/1806-0013.20160064

\section{ABSTRACT}

BACKGROUND AND OBJECTIVES: To observe chronic pain prevalence and location, to evaluate psychosocial factors and to investigate the association between psychosocial job aspects and chronic pain.

METHODS: Crossover study carried out with 23 professors of two schools of the city of Serrana/SP. Chronic pain prevalence, intensity, duration and anatomic location were evaluated. Job Content Questionnaire was used to evaluate psychosocial factors. Data were submitted to descriptive analysis with absolute and relative frequency measurements, Mann-Whitney test and Spearman correlation coefficient.

RESULTS: Musculoskeletal pain was reported by $69.6 \%$ (16) of professors, with mean symptom duration of 96.13 months $(\mathrm{SD}=104.84)$ and mean intensity of $6.37(\mathrm{SD}=2.41)$. There has been significant association between chronic pain and sleep hours. With regard to psychosocial factors, 52.2\% (12) of professors had poor job control and 52.2\% (12) have referred poor social support.

CONCLUSION: Chronic pain prevalence was high among professors and worrying psychosocial factors were observed, such as highly demanding job and poor social support.

Keywords: Chronic pain, Education, Employees' health, Professors, Psychosocial factors.

\footnotetext{
1. Santa Casa de Misericórdia de Passos, Núcleo de Estudos e Pesquisas em Trabalho, Participaçâo Social e Saúde, Uberaba, MG, Brasil.

2. Universidade Federal do Triângulo Mineiro, Instituto de Ciências da Saúde, Departamento de Terapia Ocupacional, Núcleo de Estudos e Pesquisas em Trabalho, Participação Social e Saúde, Uberaba, MG, Brasil.

Submitted in May 23, 2016.

Accepted for publication in August 22, 2016.

Conflict of interests: none - Sponsoring sources: none.

Correspondence to:

Fabiana Caetano Martins Silva e Dutra

Núcleo de Estudos e Pesquisas em Trabalho, Participaçâa Social e Saúde, Universidade Federal do Triângulo Mineiro

Av. Getúlio Guaritá, 159, sala 329, 3º piso, Centro Educacional

38025-440 Uberaba, MG, Brasil.

E-mail: fabiana@to.uftm.edu.br

(C) Sociedade Brasileira para o Estudo da Dor
}

\section{RESUMO}

JUSTIFICATIVA E OBJETIVOS: Verificar a prevalência e localização da dor crônica, avaliar os fatores psicossociais e investigar a associação entre aspectos psicossociais do trabalho e dor crônica.

MÉTODOS: Estudo transversal realizado com 23 docentes de duas escolas da cidade de Serrana/SP. Foi avaliada a prevalência, intensidade, tempo e localização anatômica da dor crônica. Para avaliar os fatores psicossociais utilizou-se o Job Content Questionnaire. Os dados foram submetidos à análise descritiva com medidas de frequência absoluta e frequência relativa, teste MannWhitney e o coeficiente de correlação de Spearman.

RESULTADOS: 69,6\% (16) professores relataram presença de dor musculoesquelética, com tempo médio de sintoma de 96,13 meses $(\mathrm{DP}=104,84)$ e intensidade média de 6,37 $(\mathrm{DP}=2,41)$. Observou-se associação significativa entre dor crônica e horas de sono. Em relação aos fatores psicossociais $52,2 \%$ (12) dos professores possuíam baixo controle sobre o trabalho, e 52,2\% (12) referiu baixo suporte social.

CONCLUSÁO: A prevalência de dor crônica foi alta entre os professores e encontrou-se presença de fatores psicossociais preocupantes, como um trabalho de alta exigência e baixo suporte social.

Descritores: Docentes, Dor crônica, Educação, Fatores psicossociais, Saúde do trabalhador.

\section{INTRODUCTION}

Pain is considered chronic when lasting more than a reasonable time for injury healing and for more than three months; it may be continuous or recurrent ${ }^{1,2}$. The transition from acute to chronic pain is still not clear, as well as triggering factors leading to chronicity.

Studies estimate that chronic pain is the most prevalent symptom among Brazilians looking for healthcare services and its incidence may vary from 7 to $40 \%$ of world population ${ }^{3}$. Chronic pain may lead to changes in lifestyle, drug dependence, social isolation, impairment of identity and selfesteem. In this process, some occupational roles are impaired and individuals may develop a feeling of inutility ${ }^{4}$.

Other consequences of chronic pain are emotional changes, difficulty to perform daily activities ${ }^{5}$, difficulties at work which may lead to medical leave, unemployment or retirement and, as consequence, distress for losing their role as 
workers $^{4,6}$. A study carried out in Salvador has shown that $41.4 \%$ of its population suffer with chronic pain and that the highest prevalence is among middle-aged adults (40 to 49 years old $)^{7}$. These same authors discuss that the presence of pain in this age group may be associated to work and working conditions of these people ${ }^{7}$. Studies point to the relationship between chronic pain and ergonomic factors of work, such as repeatability, manual handling of weight and inadequate postures $^{8-10}$.

There are also evidences that pain onset or maintenance are associated to organizational and psychosocial factors, such as long working hours, high demand, pressure for time and productivity and social working environment ${ }^{10-12}$. So, in the working environment, illnesses are largely determined by the type of work and the way it is organized, exposing some groups of workers to higher risk of developing chronic pain ${ }^{14}$. In Brazil, as from the1990s, there has been increase in the number of studies investigating working conditions and health of professors. Cardoso et al. ${ }^{15}$, in a census study with 4496 professors of the city of Salvador, have identified that work overload, together with unfavorable psychosocial aspects of the working environment, may lead to the development or worsening of chronic conditions, such as pain. In this study, chronic pain was a relevant health problem among professors, being associated to impaired labor activity with decreased performance or withdrawal from work activities $^{15}$. Analyzing epidemiologic rates, this group of professors had high prevalence of chronic musculoskeletal pain, being $41 \%$ in lower limbs, $23.7 \%$ in upper limbs and $41.1 \%$ in the back ${ }^{16}$.

A study carried out in Natal/RN has found prevalence of $63 \%$ of musculoskeletal symptoms in professors of the municipal network and a negative association of these symptoms with participants' quality of life ${ }^{13}$. Carvalho \& Alexandre ${ }^{17}$ has shown prevalence of musculoskeletal symptoms in $90.4 \%$ of public network professors of a country town of the State of São Paulo. In Vitória da Conquista/BA, 55\% of basic education professors of the private network had musculoskeletal pain $^{10}$.

Fontana ${ }^{18}$ stresses that, associated to chronic pain, professors may have important complications, such as psychic distress, mental tiredness, insomnia, anxiety, depression and stress. This author highlights that factors inherent to the process itself and organization of the teaching activity may act as stressors, precipitate diseases and/or generate dissatisfactions, such as time pressure due to productivity goals, constant demand of courses and updates, hierarchical relations conflicts, lack of decision-making autonomy, difficulties to contact colleagues during working hours and lack of social support, in addition to depreciation and disrespect on part of students, interfering with professors' quality of life and work ${ }^{18}$.

So this study aimed at evaluating the prevalence and location of chronic pain of basic education professors of two municipal schools of Serrana/SP, at evaluating working psychosocial factors and at analyzing the association between chronic pain and psychosocial factors in this group of professors.

\section{METHODS}

This is a quantitative, observational and cross-sectional study. Sample was made up of professors of two Municipal Schools selected by the Municipal Department of Education of the city of Serrana, which is a small country town of the state of São Paulo. According to census, Serrana has an estimated population of 41.728 inhabitants with Municipal Human Development Index (IDHM) of $0.729^{19}$. According to Educational Census statistics of 2012 carried out by the Ministry of Education, Serrana has 29 schools divided in pre-school, basic education and high school, being 13 of them basic education schools with 6106 enrolled students. School 1 "Professora Dalzira Barros Martins" is dedicated to pre-school and basic education from the $1^{\text {st }}$ to the $5^{\text {th }}$ year and has 22 professors. School 2, "Elizabeth Sahão" has 20 professors and is dedicated to basic education from the $1^{\text {st }}$ to the $5^{\text {th }}$ year.

All professors active during the research period, with teaching time of at least one year were invited and have voluntarily accepted to participate in the study. Exclusion criteria were professors not working in the research period and those working for less than six months in the selected schools. Schools participating in this study were indicated by the Municipal Department of Education for having a larger number of professors with teaching time of at least one year. Data were collected between July 2014 and January 2015. From 42 professors of the schools participating in the study, only 23 have met inclusion criteria.

\section{Instrumentation and procedures}

Initially the board of directors of indicated schools was contacted to schedule and organize data collection. Questionnaires were delivered to professors in the intervals between classes and during weekly meetings (professors meeting). During data collection, one author was present to answer possible questions which could be raised while professors answered the questionnaire.

To collect socio-demographic and occupational information a questionnaire was developed with information about gender, age, marital status, number of children, education level, practice of physical activity (defined as at least three times a week during 30 minutes), teaching practice time, time working for the school, number of schools where they work, number of shifts, number of students and number of classrooms, and weekly workload.

Pain was measured in three perspectives: pain intensity, duration and anatomic location. In the same socio-demographic questionnaire, professors would answer the question about presence or not of pain. If yes, participants would identify symptoms duration and affected anatomic region(s). Professors reporting pain for more than three months were classified as having chronic pain ${ }^{1}$. Visual analog scale (VAS) was used to evaluate pain intensity. This is a scale similar to a ruler, numbered from zero to 10 , where zero means no pain and 10 unbearable pain ${ }^{20}$. 
Job Content Questionnaire (JCQ) or the demand-control model proposed by Karasek were used to evaluate psychosocial factors ${ }^{21}$. This tool has 49 questions related to having control over work, psychological demand, physical demand, social support at work, insecurity at work and a question about qualification level required for the job ${ }^{22}$. According to Augusto $^{23}$, scores of different areas are calculated in a likert scale varying from 1 to 4 , being 1 = strongly disagree; 2 = disagree; 3 =agree; $4=$ strongly agree. Final score is grouped in three major areas: control over work, psychological demand and social support.

So, these variables are combined and participants are classified in levels of psychological demand and control, resulting in classifications of active work, passive work, low demand and highly demanding work. This evaluation tool of work psychosocial factors is widely used in the literature and has been translated into Portuguese by Araújo ${ }^{21}$ and validated by Araújo and Karasek ${ }^{24}$.

\section{Statistical analysis}

Investigated variables were described for sample characterization, being used descriptive measures for quantitative variables and absolute and relative frequency measures for categorical variables. Mann-Whitney $U$ test was used to compare psychosocial factors (demand, control and support) between professors not feeling pain and those with chronic pain. Spearman correlation coefficient was used to evaluate the association between psychosocial factors (demand, control and support) and pain intensity. For all statistical tests, significance level was 5\% and analyses were performed in the statistical software SPSS (Statistical Package for the Social Sciences) version 20.0

This study was approved by the Research Ethics Committee, Universidade Federal do Triângulo Mineiro (CEP/UFTM) under protocol 986.830/2014.

\section{RESULTS}

Sample was made up of 23 professors, mean age of $42 \pm 8.3$, all females $(100 \%)$, most were married $(78.3 \%)$ with mean of 1.23 children. With regard to lifestyle, $52.2 \%$ were sedentary and, after analyzing rest period, sleep hours were $6.86 \pm 1.08$ hours.

With regard to qualification, $43.5 \%$ (10) have reported having attended some specialization. Mean time working as professors was $18.52 \pm 7.31$ years and time working for the schools was $11.39 \pm 7.95$ years. In total, mean number of students per classroom reported by professors was 40.81 students and each professor taught in average to 2.30 classrooms. Most professors worked in two shifts $(60.9 \%)$ and had $34.68 \pm 13.61$ weekly working hours, with minimum of nine and maximum of 60 hours. Table 1 shows complete description of sociodemographic and occupational characteristics, and lifestyle of participants.

With regard to prevalence of chronic pain, 69.6\% (16) of professors have reported musculoskeletal pain, varying from two to 300 months (25 years). In general, mean time from symptom onset was $96.13 \pm 104.84$ months (eight years), with mean intensity of $6.37 \pm 2.41$ points in VAS (minimum of zero and maximum of 10). Pain was more frequent in lumbar spine, followed by cervical spine, shoulders and neck. At evaluation, some professors have also reported pain unrelated to musculoskeletal factors, such as headache and abdominal, ear and throat pain, as shown in table 2 .

Table 1. Demographics ( $n=23)$, Uberaba, MG, 2015

\begin{tabular}{|c|c|c|}
\hline Variables & Frequency & (\%) \\
\hline \multicolumn{3}{|l|}{ Gender } \\
\hline Male & 0 & - \\
\hline Female & 23 & 100.0 \\
\hline \multicolumn{3}{|l|}{ Age (years) } \\
\hline $20-29$ & 3 & 13.04 \\
\hline $30-39$ & 4 & 17.39 \\
\hline $40-49$ & 13 & 56.52 \\
\hline $50-59$ & 3 & 13.04 \\
\hline \multicolumn{3}{|l|}{ Marital status } \\
\hline Single & 4 & 17.4 \\
\hline married & 18 & 78.3 \\
\hline Separate or divorced & 1 & 4.3 \\
\hline Widow & 0 & - \\
\hline \multicolumn{3}{|l|}{ Education level } \\
\hline Graduation & 13 & 56.5 \\
\hline Specialization & 10 & 43.5 \\
\hline \multicolumn{3}{|l|}{ Regular physical activity } \\
\hline Yes & 11 & 47.8 \\
\hline No & 12 & 52.2 \\
\hline \multicolumn{3}{|l|}{ Worked shifts } \\
\hline Morning or afternoon & 9 & 39.1 \\
\hline Morning and afternoon & 14 & 60.9 \\
\hline \multicolumn{3}{|c|}{ Chronic musculskeletal pain } \\
\hline Yes & 16 & 69.6 \\
\hline No & 7 & 30.4 \\
\hline
\end{tabular}

Table 2. Anatomic distribution of painful symptoms in professors of the municipal network of Serrana, SP. $(n=23)$

\begin{tabular}{llc}
\hline Anatomic location Frequency (\%) & \\
\hline Musculoskeletal pain & Neck & 4.34 \\
& Shoulders & 8.69 \\
& Spine (Cervical) & 17.39 \\
& Spine (Lumbar) & 30.43 \\
& Spine & 8.69 \\
& Knee & 4.34 \\
Others & Head & 21.73 \\
& Abdominal & 4.34 \\
& Ear & 4.34 \\
& Throat & 4.34 \\
\hline
\end{tabular}


Psychosocial aspects of professors' work have shown that $47.82 \%$ (11) had low control over their work; $47.8 \%$ (11) suffered high demand and $52.2 \%$ (12) referred poor social support. Considering subgroups of the Demand-Control Model (Figure 1), it was possible to observe in quadrant 1 that $30.43 \%$ (7) of participants were classified with active work (high demand and high control); seven professors (30.43\%) were classified as low demand work (low demand and high control), represented in the third quadrant.

Finally, $21.73 \%$ (5) of professors were classified as passive work (low demand and low control). It was possible to observe that nine professors $(39.1 \%)$ had jobs with "high risk for illness", and for 14 professors (60.9\%) work was classified as "motivating and bringing wellbeing".

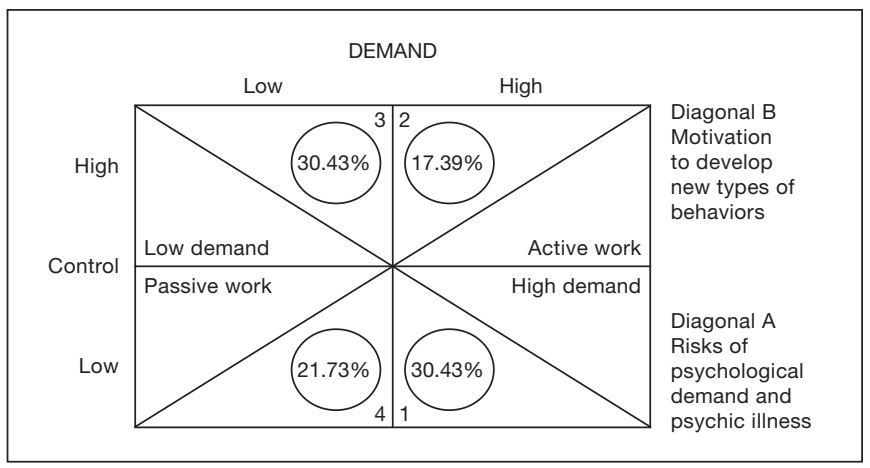

Figure 1. Representation of the demand-control model

\section{Chronic pain and socio-demographic and working char- acteristics}

There has been no association between chronic pain and workload ( $\mathrm{p}=0.730)$, but there has been significant association between chronic pain and sleep hours, indicating that professors with chronic pain were those reporting less sleep hours per night $(\mathrm{p}=0.024)$. There has been no correlation between pain intensity and sleep hours $(\mathrm{p}=0.833 ; \mathrm{r}=-0.048)$; and between pain intensity and workload ( $\mathrm{p}=0.696 ; \mathrm{r}=-0.088)$.

\section{Work psychosocial factors and socio-demographic and working characteristics}

Comparison between demand and sleep hours has shown that professors with high demand were those sleeping less hours per night $(\mathrm{r}=-0.580 ; \mathrm{p}=0.005)$. Lower work demand was significantly correlated to older age among professors $(\mathrm{r}=-0.534, \mathrm{p}=0.009)$. In analyzing support and workload there has been significant association between weekly workload and support, pointing that professors with higher social support at work are those with longer weekly working hours $(\mathrm{r}=0.507, \mathrm{p}=0.016)$. When work organization variables were compared (number of students, number of classrooms and workload), there has been statistically significant difference between risk of illness and number of students, indicating that professors who teach for a higher number of students are at increased risk for illness $(\mathrm{p}=0.032)$.

\section{Chronic pain and psychosocial work factors}

When psychosocial factors were compared between painless professors and those reporting chronic pain, there has been no statistically significant difference. This result shows that there is no difference in demand ( $\mathrm{p}=0.871)$, control $(\mathrm{p}=0.871)$ and social support $(\mathrm{p}=0.175)$ between both groups of professors. Correlation analysis between pain intensity and psychosocial factors has also not shown significant association, suggesting that pain intensity in this group is not associated to control ( $\mathrm{p}=0.053)$, demand $(\mathrm{p}=0.693)$ or social support at work $(\mathrm{p}=0.336)$. However, pain intensity was significantly associated to specific social support by colleagues, indicating that professors with higher support of colleagues have reported less severe pain $(\mathrm{p}=0,044 ; \mathrm{r}=-0,423)$.

\section{DISCUSSION}

Our study has shown predominance of female professors, similar to what has been found by other studies indicating the prevalence of females working as professors ${ }^{7,10,11,13,17,21,25}$. Feminization of teaching, considering the relative weigh of females in the composition of a profession or occupation, may be explained by the historical process of the entering of females in the work market, being teaching labeled as an activity of "care" and as continuity of housework ${ }^{13,14}$. So, education is a profession predominantly practiced by females. In Brazil, according to United Nations Organization for Education, Science and Culture (UNESCO) ${ }^{26}$ research on the profile of professors, $81.3 \%$ of professors are females. Participants' age, mean above 40 years, also matches Brazilian professors' profile, where the highest proportion is between 36 and 45 years of age ${ }^{25}$. Considering the international scenario, age profile of this group of professors is also equivalent to most professors belonging to the Organization of Cooperation and Economic Development (OCED) and of some European Union countries, who are above 40 years of age ${ }^{26}$. Considering that age is a factor which could be associated to chronic pain prevalence, more than half the sample $(69.6 \%)$ has reported musculoskeletal pain. Kreling $^{27}$ points to increasing prevalence of chronic pain with age, reaching its prevalence peak between 30 and 50 years of age and a trend to higher pain frequency with increased age. With regard to frequency and intensity, participants of this study have reported pain with mean duration of eight years and mean intensity of 6.37 according to VAS.

Another aspect associated to pain is sedentary lifestyle, or not regularly practicing physical activities. In our study, more than half of participants did not perform any type of physical activity. Fernandes et al. ${ }^{28}$ have included in their study sedentary lifestyle as positive gradient for the onset of musculoskeletal disorders, showing that the practice of physical activities may be a protecting factor against pain. However, Mango ${ }^{11}$, when evaluating 126 basic education professors of a country town of Paraná, has not found association between musculoskeletal symptoms and practice of physical activity. 
All professors participating in this study had college graduation, as provided by the Lei de Diretrizes e Bases da Educação Nacional (LDB) ${ }^{16,29}$ and just under half of them (43.5\%) have reported having attended some specialization. In the literature, the study by Fernandes ${ }^{13}$ has shown similar percentage of professors (42.4\%) who continued their qualification process after graduation. As to professional practice time (18.52 years), participants of our study had years of professional practice relatively above time found in most previous studies, where mean practice time has varied between 10 to 14 years $^{9-11,24,29}$.

However, teaching practice time measured in this study is similar to data found by Fernandes ${ }^{13}$ among professors of the municipal network of Natal/RN, where mean teaching practice time was 18.25 years. Also close to these findings, Carvalho \& Alexandre ${ }^{17}$, in his study with professors of the public network of a country town of the state of Sáo Paulo, has found mean working time as professors of 16.4 years, characterizing a stable work. In a study also describing teaching practice time in a same school, $60.5 \%$ of professors worked for less than five years in the same school and just $39.4 \%$ for more than five years ${ }^{15}$.

Weekly and daily working hours were another studied variable. Professors worked in average 34.69 weekly hours, more than half of participants $(60.9 \%)$ worked in two shifts, mean number of students per classroom was 40.81 and each professor taught for, in average, 2.30 classrooms. These labor characteristics configure professional performance marked by intense working hours, similar to what has been found by other studies with professors. Ribeiro ${ }^{10}$ describes professors working in two shifts, with more than 30 students per classroom and during 40 or more weekly hours.

In the study by $\mathrm{Calixto}^{29}$, mean workload was 40.03 weekly hours with mean of 38.07 students per classroom. Cardoso ${ }^{15}$ points to the number of students as risk factor for musculoskeletal symptoms in UULL. The hypothesis is that a larger number of students demands further effort from professors, both inside and outside classroom. Mango ${ }^{11}$ has found significant association between the number of classrooms (1.9 classrooms per professor) and the presence of musculoskeletal symptoms for more than three months.

In general, it is difficult to measure time worked by professors. Commonly, the calculation is done with teaching time measured in hours of presence before students. However, activities and tasks, such as preparing and correcting exercises, tests and schoolwork, contact with parents and students, among others, are performed outside the school, often at home. Seabra and Dutra ${ }^{12}$, analyzing the distribution of time of professors' daily activities, have identified increase in mean hours dedicated to work during weekends. Added to intensified teaching, one should have in mind that, with regard to females, extensive workload is not limited to labor activities, but also to activities such as taking care of home and children, thus making up two working shifts ${ }^{13,14}$.

It is possible to find in the literature the consequences of extensive working hours and of teaching. According to Reis et al. ${ }^{30}$, workload above 35 weekly hours might be associated to mental tiredness and nervousness; while dedication of 40 weekly hours with minimum breaks, is characterized as risk factor for professors' health complication ${ }^{31}$.

Branco $^{25}$ relates severe pain, musculoskeletal diseases and changes in quality of life and emotional status of professors to work intensification and to performing work activities at home. In light of this context of replacing rest and leisure activities by more time dedicated to work, Seabra and Dutra ${ }^{12}$ have stressed the importance of maintaining a balance between labor activities and participation in activities of personal care and leisure which promote wellbeing and health. A concern with regard to participants' health and wellbeing is self-reported sleep hours. Mean sleep hours was 6.86 and was associated to chronic pain, indicating that professors with chronic pain were those reporting sleeping less hours per night.

Specifically discussing pain perception, lumbar region (30.43\%), followed by cervical spine (11.39\%), shoulders (8.69\%) and neck (4.34\%) were body sites with the highest prevalence of musculoskeletal pain. These results are consistent with other studies with professors indicating lumbar region, cervical spine, head and lower and upper limbs as most prevalent regions ${ }^{713,25}$. Kreling et al. ${ }^{27}$ have described most affected regions as head, lumbar, sacral and coccyx regions, followed by lower limbs and back, and $23.7 \%$ in upper limbs.

Factors specifically related to teaching practice and how this work is organized may be related to the onset and maintenance of musculoskeletal pain, such as remaining for too long in the upright position, writing on the blackboard, going up and down stairs, inadequate school materials, equipment and furniture, carrying didactic material, correction of tests and exercises, and commuting from one school to the other for professors working in two shifts ${ }^{10,14}$. Ribeiro ${ }^{10}$ describes association of low back pain and body flexion movement and maintenance of the upright position, common in professors' daily lives, especially going to the desk to answer students' questions. In addition to biomechanical factors, other studies point to the association of chronic pain and dissatisfaction with work, profession practice time and professor-student relationship wear ${ }^{11,15,30,32}$.

Considering work psychosocial characteristics, evaluated by JCQ, it was observed that half the professors have low control over their work and the other half reported low social support. The lack of control over work brings negative consequences to health and contributes to increase stress ${ }^{30}$. Only specific social support of colleagues was significantly associated to chronic pain intensity. Professors with higher support offered by colleagues have reported less severe pain. Remaining psychosocial aspects have not indicated significant association with chronic pain perception and intensity. However, the picture presented by participants is in itself relevant and should be carefully analyzed. Araújo ${ }^{21}$ relates the prevalence of health problems associated to low control over work, to high psychological demand in performing the 
work and aspects relative to the environment and organization of the teaching practice. Another study has found higher prevalence of nervousness and mental tiredness among professors reporting poor social support ${ }^{30}$.

In demand-control model groups, half of professors are exposed to high demand. Cardoso ${ }^{15}$ points that exposure to highly demanding work is a risk factor for the development of musculoskeletal pain, as compared to low demand works. The combination of the exposure to high demand and low control is related to higher percentages of noxious effects to health, such as risk of falling ill ${ }^{21}$. Cardoso ${ }^{15}$ describes association between professors exposed to high demand and active work and higher prevalence of musculoskeletal pain. It is also possible to find association between highly demanding work and low social support and the prevalence of common mental disorders ${ }^{14,21,30,32,33}$.

In our study, low working demand was significantly correlated to older age. According to some studies, this is due to time of teaching practice. In general, younger workers are susceptible to higher working demand for being in the beginning of their career, engaging in different activities and tasks and being exposed to a higher level of stress; consequently, younger professors are susceptible to early pain symptoms $s^{9,17,30}$.

Reis et al. ${ }^{30}$ discuss that professors with longer professional experience, such as older professors, are those presenting less negative working effects on their health. Mean working time in the same school was high, thus making up a group of workers with stable employment. Literature has shown disadvantage of time working in the same school, with association of tiredness and stable employment ${ }^{30}$, contesting the hypothesis that time working for a same school could be a protective factor.

As to working hours, those with longer weekly hours were professors with higher social support at work. Few studies discuss social support and its relationship among professors. Porto et al. ${ }^{33}$ point that workers with low social support have up to twice more risk of presenting psychic disorders. Delcor et al. $^{14}$, in turn, highlight as positive factor in the working environment professors' affective and relational area, being support of colleagues appreciated by participants of the study. Results also show that high demand and large number of students per professor were working factors associated to poor health indicators, that is, higher risk of falling ill and less sleep hours per night. Ribeiro ${ }^{10}$, in a study with professors of municipal basic education network of Salvador, Bahia, has found association between upper limbs pain and high number of students per classroom.

Cardoso", in a study with professors of the municipal children and basic education network of Salvador, Bahia, reports the number of students as risk factor for upper limbs musculoskeletal pain, since this leads professors to have more activities, such as correction and planning of school activities, in addition to more material being carried to the classroom $^{10}$. In addition to professors health problems, there is influence in students' learning, being recommended by the
International Labor Organization (ILO) that the number should not exceed 25 students per classroom ${ }^{29}$.

It is important to consider some limitations of this study. Due to the number of available schools for investigation and to some inclusion criteria such as minimum time working for the school, the sample was restricted to 23 professors. This sample size may explain the lack of association between chronic pain and psychosocial work factors in this group of professors. Another possible explanation might be the long time professors worked for the same school, which provides more chances of workers to develop strategies to cope with psychosocial factors.

However, although the small sample size, it has the same socio-demographic characteristics of the Brazilian population of professors (age, gender and education level), which allows generalizations and represents a quality of the sample. The cross-sectional character of this study also limits the analysis of causal relationships. However, this study gains relevance when producing the image portraying the specific health and work situation of a group of workers, thus helping the practical application of results due to proximity with local public authorities. In face of this scenario, one should stress the importance of advancing with studies about the link between health, working conditions and working capacity. It is suggested that this investigation is expanded to remaining schools of the city, incorporating working conditions analysis, teaching practice ergonomic analysis and evaluation of other health aspects important for professors, in addition to chronic pain. So, it is critical to implement actions aimed at education workers health and working conditions improvement, as well as measures to prevent the worsening of the situation exposed by this study.

\section{CONCLUSION}

Professors of evaluated schools have moderate chronic pain, being lumbar spine, cervical spine, shoulders and neck the most affected regions. There has also been association between chronic pain and sleep hours, in addition to extensive working hours. The analysis of psychosocial factors has shown a high percentage of professors with low control over work, high demand and poor social support.

\section{REFERENCES}

1. Loeser JD, Treede RD. The Kyoto protocol of IASP basic pain terminology. Pain. 2008;137(3):473-7.

2. Salvetti Mde G, Pimenta CA. Dor crônica e a crença de auto-eficácia. Rev Esc Enferm USP. 2007;41(1):135-40.

3. de Moraes Vieira EB, Garcia JB, da Silva AA, Mualem Araújo RL, Jansen RC. Prevalence, characteristics, and factors associated with chronic pain with and without neuropathic characteristics in São Luís, Brazil. J Pain Symptom Manage. 2012;44(2):239-51.

4. Silva FC, Sampaio RF, Mancini MC, Luz MT, Alcântara MA. A qualitative study of workers with chronic pain in Brazil and its social consequences. Occup Ther Int. 2011;18(2):85-95.

5. Bracher ESB, Pietrobon R, Eluf-Neto, J. Cross-cultural adaptation and validation of a Brazilian Portuguese version of the chronic pain grade. Qual Life Res. 2010;19(6):847-852.

6. Barros N. Qualidade de vida: Conceitos e métodos de avaliaçăo. In: Andrade Filho ACC. Dor - diagnóstico e tratamento. Sáo Paulo: Roca; 2001. 53-61p.

7. Sá K, Baptista AF, Matos MA, Lessa I. [Prevalence of chronic pain and associated factors in the population of Salvador, Bahia]. Rev Saude Pública. 2009;43(4):622-30. 
8. Melzer AC. Fatores de risco físicos e organizacionais associados a distúrbios osteomusculares relacionados ao trabalho na indústria têxtil. Fisioter Pesqui. 2008;15(1):19-25.

9. Cardoso JF, Ribeiro IQ, Araújo TM, Carvalho FM, Reis EJ. Prevalência de dor musculoesquelética em professores. Rev Bras Epidemiol. 2009;12(4):604-14.

10. Ribeiro IQ, Araújo TM, Carvalho FM, Porto LA, Reis EJ. Fatores ocupacionais associados à dor musculoesquelética em professores. Rev Baiana de Saúde Pública. 2011; 35(1):42-64.

11. Mango MS, Carilho MK, Drabovski B, Joucoski E, Garcia MC, Gomes AR. Análise dos sintomas osteomusculares de professores do ensino fundamental em Matinhos (PR). Fisioter Mov. 2012;25(4):785-94

12. Seabra MM, Silva e Dutra FC. Intensificação do Trabalho e Percepção da Saúde em Docentes de uma Universidade Pública Brasileira. Cienc Trab, 2015;17(54):198-204.

13. Fernandes $\mathrm{MH}$, Rocha VM. Impacto da sintomatologia osteomuscular na qualidade de vida de professore. Rev Bras Epidemiol. 2011;14(2):276-84

14. Delcor NS, Araújo TM, Reis EJ, Porto LA, Carvalho FM, Silva MO, et al. Condiçóes de trabalho e saúde dos professores da rede particular de ensino de Vitória da Conquista, Bahia, Brasil. Cad Saúde Pública. 2004;20(1):187-96.

15. Cardoso JP, Araújo TM, Carvalho FM, Oliveira, NF, Reis EJ. Aspectos psicossociais do trabalho docente e dor musculoesquelética. Cad Saúde Pública. 2011;27(8):1498-506.

16. Cardoso JP, Ribeiro IQ, de Araújo TM, Carvalho FM, Reis EJ. Prevalência de dor musculoesquelética em professores. Rev Bras Epidemiol. 2009;12(4):604-14.

17. Carvalho AJ, Alexandre NM. Sintomas osteomusculares em professores do ensino fundamental. Rev Bras Fisioter, 2006;10(1):35-41.

18. Fontana RT, Pinheiro DA. Condiçóes de saúde auto referidas de professores de uma universidade regional. Rev Gaúcha Enferm. 2010;31(2):270-6.

19. Instituto Brasileiro de Geografia e Estatística (IBGE). Instituto Nacional de Estudos e Pesquisas Educacionais - INEP - Censo Educacional 2012. [online] Rio de Janeiro: IBGE, 2010. Disponível em: <http://www.ibge.gov.br/home/> Acesso em: 4 mar. 2016.

20. Caraviello EZ, Wasserstein S, Chamlian TR, Masiero D. Avaliação da dor e funçấo de pacientes com lombalgia tratados com um programa de Escola de Coluna. Acta Fisiátrica. 2005;12(1):11-14.

21. Araújo TM, Aquino E, Menezes G, Santos CO, Aguiar L. Aspectos psicossociais do trabalho e distúrbios psíquicos entre trabalhadoras de enfermagem. Rev Saude Publica. 2003;37(4):424-33.

22. Alves MG, Hökerberg YH, Faerstein E. Tendências e diversidade na utilização empírica do Modelo Demanda-Controle de Karasek (estresse no trabalho): uma revisão sistemática. Rev Bras Epidemiol. 2013;16(1):125-36.

23. Araújo TM, Karasek, R. Validity and reliability of the job content questionnaire in formal and informal jobs in Brazil. Scand J Work Environ Health. 2008;Suppl 6):S52-9.

24. Araújo TM, Reis EJ, Carvalho FM, Porto LA, Reis IC, Andrade JM. Fatores associados a alteraçóes vocais em professoras. Cad Saude Publica. 2008;24(6):1229-38.

25. Branco JC, Jansen K. Prevalência de sintomas osteomusculares em professores do ensino fundamental do maior colégio municipal da América Latina. Ciênc Cogn. 2011;16(3):109-15.

26. Organizaçẫo das Nações Unidas para a educação, a ciência e a cultura - UNESCO Perfil dos Professores do Brasil - O que fazem, o que pensam, o que almejam. UNES$\mathrm{CO} ; 2004$

27. Kreling MC, da Cruz DA, Pimenta CA. Prevalência de dor crônica em adultos. Rev Bras Enferm. 2006;59(4):509-13.

28. Fernandes $\mathrm{MH}, \mathrm{Da}$ Rocha VM, Costa-Oliveira ARG. Fatores associados à prevalência de sintomas osteomusculares em professores. Rev Salud Pública. 2009;11(2):256-67.

29. Calixto MF, Garcia PA, Rodrigues DS, Almeida PH. Prevalência de sintomas osteomusculares e suas relaçóes com o desempenho ocupacional entre professores do ensino médio público. Cad Ter Ocup UFSCar. 2015; 23(3):533-42.

30. Reis EJ, Araújo TM, Carvalho FM, Barbalho L, Silva MO. Docência e exaustăo emocional. Educ. Soc. 2006;27(94):229-53.

31. Marchiori F, Barros ME, Oliveira SP. Atividade de trabalho e saúde dos professores: 0 programa de formação como estratégia de intervenção nas escolas. Trab. educ. saúde. 2005; 3(1):143-70.

32. Araújo TM, Carvalho FM. Condiçóes de trabalho docente e saúde na Bahia: estudos epidemiológicos. Educ Soc. 2009;30(107):427-49.

33. Porto LA, Carvalho FM, Oliveira NF, Silvany Neto AM, Araújo TM, Reis EJ, et al. Associação entre distúrbios psíquicos e aspectos psicossociais do trabalho de professores. Rev Saúde Pública. 2006;40(5):818-26. 